\title{
Divided infraorbital foramen in the lion (Panthera leo): its implications for colonisation history, population bottlenecks, and conservation of the Asian lion (P. l. persica)
}

\author{
Nobuyuki Yamaguchi ${ }^{1,2,5}$, Andrew C. Kitchener ${ }^{3}$, Carlos A. Driscoll ${ }^{1,4}$ and David W. Macdonald ${ }^{1}$ \\ ${ }^{1}$ Wildlife Conservation Research Unit, University of Oxford, Tubney House, Abingdon Road, Tubney, Abingdon, \\ OX13 5QL UK \\ ${ }^{2}$ Department of Biological and Environmental Sciences, University of Qatar, PO Box 2713, Doha, Qatar \\ ${ }^{3}$ Department of Natural Sciences, National Museums Scotland, Chambers Street, Edinburgh, EH1 1JF UK. \\ ${ }^{4}$ Laboratory of Genomic Diversity, National Cancer Institute, Frederick, MD 21702-1201 USA. \\ ${ }^{5}$ E-mail:yamaguchi@qu.edu.qa
}

Key words: cave lion, Gujarat, India, skull, spelaea, tiger

\begin{abstract}
A divided infraorbital foramen is an important morphological feature in lion taxonomy and has previously been considered to occur only in the Asian lion, Panthera leo persica. Based on an examination of 498 lion skulls from museum collections in Europe and southern Africa, we report for the first time on the prevalence of the divided infraorbital foramen in African lions, as well as its occurrence in the tiger, P. tigris and the extinct Pleistocene European cave lion, P. leo spelaea. The higher frequency of this characteristic in Asian lions may have occurred after the lion colonised Asia, and can be considered an important morphological feature characterising this population. It is not clear whether recent anthropogenic population bottlenecks have influenced changes in its prevalence over the last 200 years.
\end{abstract}

\section{Contents}

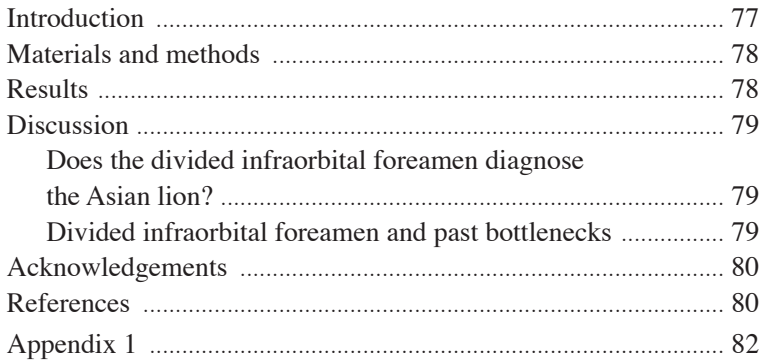

\section{Introduction}

Although Smee (1835) had clearly referred to a divided infraorbital foramen in his description of the 'maneless lion of Guzerat', it was Pocock (1930) who drew zoologists' attention to the presence of the divided infraorbital foramen (DIF) in modern lion, Panthera leo
Linnaeus, 1758 skulls from India. The infraorbital foramen is an opening in the skull, through which the infraorbital artery, the infraorbital vein and the infraorbital nerve emerge (Fig 1a). The infraorbital foramina are found below the orbits at the anterior end of the zygomatic arches of the skull and in Indian lions they are frequently divided by a bridge of bone into smaller upper and larger lower portions (Pocock, 1930) (Fig 1b). Although zoologists, including Pocock, were fully aware that DIF did not always occur in the Indian lion, it has become one of the most important morphological characteristics distinguishing the skulls of Indian and African lions (Pocock, 1930; Todd, 1965; Joslin, 1984; O'Brien et al., 1987; Rashid and Reuben, 1992; Nowell and Jackson, 1996; Srivastav and Srivastav, 1997; Divyabhanusinh, 2005; Singh, 2007). Pocock (1930) stated that DIF never occurred in the African lion and, to date, this statement has been referred to, and accepted uncritically, by subsequent authors when describing distinctions between Indian and African lion skulls. However, perhaps ironically for the importance of DIF to characterise the Indian lion, Todd (1965) suggested, based on 34 Indian lion skulls, that DIF may have been shifting its frequency of occurrence in the Indian lion in the last 200 years, declining between the $19^{\text {th }}$ century and the mid- $20^{\text {th }}$ century.

We here report on the frequency of occurrence of DIF in the African lion for the first time, and discuss whether this characteristic is useful for distinguishing Asian and African lion skulls, both for individuals and at the population level. Also, we re-examine the hypothesis presented by Todd (1965) concerning the temporal shift of the frequency of occurrence of DIF in the Indian lion based on a larger sample size. 


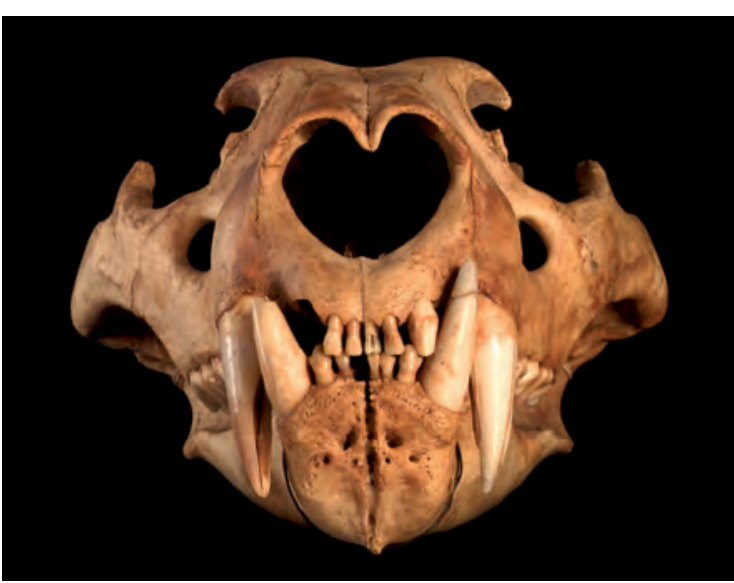

Fig 1a. Undivided infraorbital foramina of a Sub-Saharan African lion (Amathole Museum, King William's Town, South Africa, ID number: 18319, origin: Etosha Pan, Namibia) (photo: Nobuyuki Yamaguchi).

\section{Materials and methods}

We examined 498 lion skulls kept in museum collections in Europe and southern Africa, originating from as many locations as possible across the species' natural distribution, including recently extinct populations such as North African Barbary lion, Panthera leo leo Linnaeus, 1758. In addition, previously published information concerning the occurrence of DIF for $23 \mathrm{In}$ dian lion skulls (Smee, 1835; Todd, 1965) was included in the analysis. To investigate the occurrence of DIF in the nearest internally-coherent taxon to the lion, we examined skulls of the extinct Pleistocene European cave lion, P.l. spelaea (Goldfuss, 1810), which is considered to have shared a common ancestor with the modern lion as recently as at c. 500-600 thousand years ago (Burger et al., 2004; Yamaguchi et al., 2004; Barnett et al., 2009). All eight examined cave lion skulls originate from Europe. We also examined 304 tiger, P. tigris Linnaeus, 1758, skulls kept in Europe and the former Soviet Union - from as many locations as possible across its natural distribution, representing all customarily recognised subspecies (Luo et al., 2004), including three extinct ones. The occurrence of DIF was assessed as 'present' or 'absent' regardless at which side it occurred. The broken specimen recorded by Todd (1965), 'Mumbai 1261' in Appendix 1, was excluded from the analysis because it was not known whether DIF occurred in the skull. The two incomplete divisions recorded at National Museums Scotland (Edinburgh (Z.2001.174.2) and Edinburgh (Z.2008.004) see Appendix 1) were classified as DIF present (Fig 1b). All

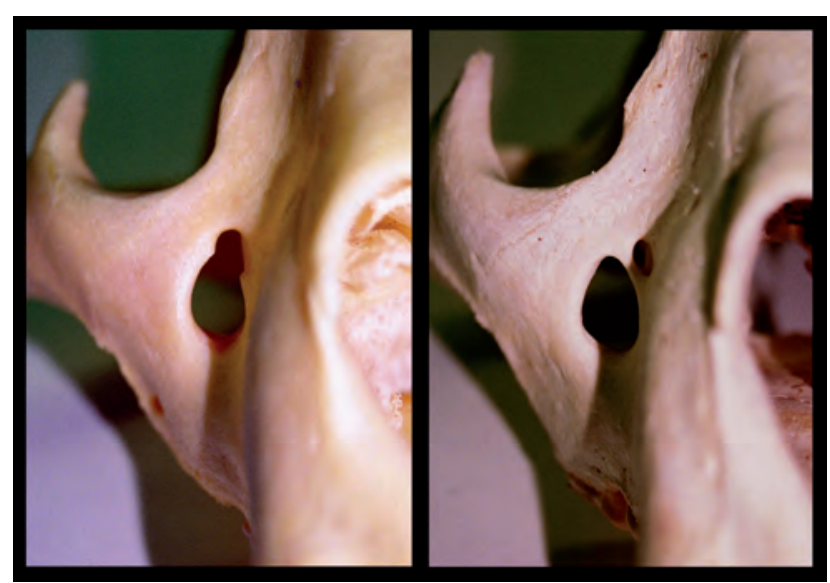

Fig 1b. A partially-divided infraorbital foramen (left: National Museums Scotland, ID number: NMS.Z.2008.004), and a divided infraorbital foramen (right: National Museums Scotland,ID number: NMS.Z.2001.185.1) of Asian lion skulls (photo: Andrew Kitchener).

statistical analyses were carried out using SPSS (SPSS Inc., Chicago, USA), and statistically significant differences were detected using the likelihood ratio chisquare test, which is also referred to as the G-test.

\section{Results}

Amongst 435 African lion skulls and ten specimens whose origins are likely to be in Africa, five (c. 1\%) had DIF (Table 1). Curiously, all African lions with DIF originated from between Tanzania and Zimbabwe, and especially from a relatively small area around Lakes Edward and Albert (central Tanzania - eastern Democratic Republic of Congo) (Appendix 1). In contrast, approximately $46 \%$ (26 out of 56) of Indian lion skulls had this characteristic (Table 1).

Two lions from Iran had DIF (Appendix 1). Amongst lions, Iranian and Indian populations are phylogenetically very similar (Barnett et al., 2006a), and customarily have been classified as the same subspecies, $P$. $l$. persica (Meyer, 1826), in which DIF therefore occurred in approximately $48 \%$ (28 out of 58) of skulls. In the African lion the skulls only had DIF either on the left side (three individuals) or on the right side (two individuals), but in the Asian lion there were seven individuals that had it on both sides (in addition to six left-sided and 13 right-sided specimens). The extinct Barbary lion is suggested to be phylogenetically closer to the Asian lion than to sub-Saharan lions (Barnett et al., 2006a) and yet, amongst the 12 skulls we examined, none had a DIF (Table 1, Appendix 1). 
In terms of the frequency of occurrence of DIF, there were statistically significant differences between Asian and African lions (G-test, two tailed, $N=503, d f=1$, likelihood ratio $\left.\chi^{2}=108.4, P<0.001\right)$, as well as between Asian and Barbary lions (G-test, two tailed, $N=$ $70, d f=1$, likelihood ratio $\left.\chi^{2}=13.9, P<0.001\right)$, whilst a statistically significant difference was not detected between Barbary and sub-Saharan African lions (Gtest, two tailed, $N=445, d f=1$, likelihood ratio $\chi^{2}=$ $0.3, P=0.60)$. In comparison to the lion where DIF occurred in more than $5 \%$ of all examined skulls, it occurred only in c. $0.3 \%$ (one out of 304) of tiger skulls (lion vs tiger: G-test, two tailed, $N=807, d f=1$, likelihood ratio $\chi^{2}=25.0, P<0.001$ ), and in $13 \%$ (one out of eight) of examined skulls of the extinct Pleistocene European cave lion (lion vs. cave lion: G-test, two tailed, $N=511, d f=1$, likelihood ratio $\chi^{2}=0.4, P=0.55$ ).

Divided infraorbital foramen occurred in $45 \%$ $(5 / 11)$ of Indian lion skulls collected in the $19^{\text {th }}$ century, which rose to $67 \%(10 / 15)$ in the early $20^{\text {th }}$ century (pre-1950, including those without recorded collecting dates, yet likely to have been collected during this period as indicated by from their museum register numbers), but this fell to $38 \%$ (13/29) post-1950 (Table 2).

However, no statistically significant difference was detected by the G-test at the significant level of 0.05 either between those three periods or between any dyads, although a marginally significant difference was detected between pre- and post-1950 samples (G-test, two tailed, $N=44, d f=1$, likelihood ratio $\chi^{2}=3.32, P$ $=0.069)$.

\section{Discussion}

Does the divided infraorbital foramen diagnose the Asian lion?

Two lions from Iran have DIF (Appendix 1), contradicting the hypothesis that DIF distinguishes the skulls

Table 1. Observations on the presence / absence of the divided infraorbital foramina (DIF) in lion, European cave lion, and tiger.

\begin{tabular}{lrr}
\hline Species/Population & With DIF & Without DIF \\
\hline Lion & 33 & 487 \\
\hline \multicolumn{1}{c}{ Asian } & 28 & 30 \\
African & 5 & 440 \\
$\quad$ Barbary & 0 & 12 \\
\hline European cave lion & 1 & 7 \\
\hline Tiger & 1 & 303 \\
\hline
\end{tabular}

of Indian lions from Gujarat, from not only those of all other lions, including other Asian lions, but also from those of all other felids (O'Brien et al., 1987). Although our results show that DIF is not exclusive to the Gir Forest lions, it can be confidently reported that DIF rarely appears in sub-Saharan African lions, which, on the basis of a molecular phylogeny, are likely to be ancestral to the North African -Asian population (Barnett et al., 2006a). Also, our results suggest that the extinct North African Barbary lion does not seem to have DIF, at least at a high frequency. Furthermore, it is suggested based on maternally inherited mitochondrial DNA, that the modern lion does not appear to have hybridised with the extinct northern Holarctic lions of the Pleistocene, including the European cave lion (Burger et al., 2004; Barnett et al., 2009), where 13\% have DIF. Therefore, a higher DIF frequency in the Asian population may be a characteristic that developed after the lion colonised Asia, potentially reflecting the recent colonisation history of the lion. These arguments suggest that the higher frequency of DIF in Asian lions is still an important morphological feature that distinguishes their skulls from those of African lions, even though we now know that some African individuals have it.

\section{Divided infraorbital foramen and past bottlenecks}

Todd (1965) speculated that the degree of expression and/or penetrance of DIF are under the influence of only a few polygenes, which have shown shifts in frequency in the Indian lion population, possibly due to genetic drift. As the phylogenetic ancestor of the Asian lion (i.e. the sub-Saharan African lion: Barnett et al., 2006a) does not show a high prevalence of DIF, has the Asian lion experienced any severe population/genetic bottleneck in the past, where genetic drift (and/or founder effect) could have been a major factor influencing the frequency of occurrence of the population's genetic and morphological characteristics? Driscoll et

Table 2. Observations on the presence / absence of the divided infraorbital foramina (DIF) in Indian lion skulls over time.

\begin{tabular}{lcc}
\hline Period & With DIF & Without DIF \\
\hline $19^{\text {th }}$ Century & 5 & 6 \\
Pre-1950 & 10 & 5 \\
Post-1950 & 13 & 16 \\
\hline
\end{tabular}


al. (2002) suggested, based on an analysis of $88 \mathrm{nu}-$ clear microsatellite loci, that the extreme genetic homogenisation in the current Gir Forest lion population results from a population genetic bottleneck around 1,100 - 4,300 years ago, which was probably caused by natural events.

A more recent, and probably human-caused, population bottleneck appears to have been most severe at the end of the $19^{\text {th }}$ century when it was estimated that 'no more than ten or a dozen' individuals survived (Fenton, 1909; Kinnear, 1920; Wynter-Blyth and Dharmakumarsinhji KS, 1949; Dharmakumarsinhji and Wynter-Blyth, 1950; Talbot, 1960), although the severity of this bottleneck may have been exaggerated (Srivastav and Srivastav, 1997; Divyabhanusinh, 2005). Todd (1965) analysed the temporal change in frequency of DIF in Indian lions - DIF occurred in 85\% (4/5) of Indian lion skulls collected in the $19^{\text {th }}$ century, and $60 \%(6 / 10)$ of early $20^{\text {th }}$ century skulls (pre-1950: 1910-1931), whilst only 27\% (5/18.5: Todd (1965) gave the broken specimen (Mumbai 1261: Appendix 1) 0.5 ) had DIF in post-1950 specimens. Our results based on a larger sample indicate that DIF occurs in $45 \%(5 / 11)$ of Indian lion skulls collected in the $19^{\text {th }}$ century, which rises to $67 \%(10 / 15)$ in the early $20^{\text {th }}$ century (pre-1950, including those without recorded collecting dates yet likely to have been collected during this period as indicated by from their museum register numbers), but this falls to $38 \%$ (11/29) post- 1950 . There is no detectable significant differences in prevalence of DIF between these periods, and therefore the results do not support the previous hypothesis that there have been considerable shifts in DIF frequency over the past 200 years (Todd 1965). Granted, the combined sample size is still small, and there is a possibility that the sample is not a fair representation of the population. Also, we emphasise that there is a marginally statistically significant difference between pre1950 and post-1950 samples, which may be strong enough for scientists to further investigate this issue. In other words, it may be possible that the recent anthropogenic population bottleneck and subsequent population increase (Nowell and Jackson, 1996) have influenced the prevalence of this population-specific characteristic of Asian lions. The foregoing arguments suggest that, although the shift may not be as dramatic as Todd (1965) speculated, conservationists may need to monitor carefully the morphological characteristics of the Asian lion both in the wild and in captivity. Captive breeding programmes for the Asian lion in Europe and India provide a unique opportunity to study the inheritance of DIF and other morphological characteristics in the Asian lion, in order to better understand changes in the prevalence of these characters in historical wild populations.

\section{Acknowledgements}

We thank the European Union SYNTHESYS programme for allowing NY to visit the National Museum of Natural History, Paris, France, Museum of Natural History, Berlin, Germany, and Royal Museum for Central Africa, Tervuren, Belgium, to examine skulls, and British Airways for transport between the UK and Kazakhstan. We also thank Daphne Hills, Paula Jenkins, Louise Tomsett (Natural History Museum, London), Malgosia Nowak-Kemp (Natural History Museum, University of Oxford, Oxford), Malcolm Harman (PowellCotton Museum, Kent, UK), Robert Asher, Peter Giere, Irene Thomas (Museum of Natural History, Berlin), Thomas Martin, Katrin Krohmann (Senckenberg Research Institute and Natural History Museum, Frankfurt am Main), Doris Mörike (State Museum of Natural History, Stuttgart, Germany), Jacques Cuisin, Francis Renoud, Daniel Robineau, Michel Tranier (National Museum of Natural History, Paris), Marie-Dominique Wandhammer, Virginia Rakotondrahaja (Zoological Museum, Strasbourg, France), Vincent Nijman, Peter van Bree, Adri Rol (Zoological Museum, University of Amsterdam, Amsterdam), Chris Smeenk, Hein van Grouw (National Museum of Natural History, Leiden, The Netherlands), Emmanuel Gilissen, Wim Wendelen (Royal Museum for Central Africa, Tervuren, Belgium), Lars Werdelin, Bo Fernholm, Olavi Grönwall (Swedish Museum of Natural History, Stockholm, Sweden), Alexei Abramov, Alexei Tikhonov (Zoological Institute, Russian Academy of Sciences, Saint Petersburg), Igor Ya. Pavlinov, Alex Borissenko, Sergey Kruskop (Zoological Museum, Moscow State University, Moscow), Elena Zholnerovskaya, Natasha Lopatina (Siberian Zoological Museum, Novosibirsk, Russia), Vitaliy Gromov (Institute of Soil Science, Almaty), Vitaliy Kascheev, Amankul Bekenov, Roman Jashenko (Institute of Zoology, Almaty, Kazakhstan), Woody Cotteril (Natural History Museum, Bulawayo, Zimbabwe), Duncan MacFadyen (Transvaal Museum, Pretoria), Fred Kigozi (Amathole Museum, King William's Town), Gillian Watson (Port Elizabeth Museum Complex, Port Elizabeth), Denise Drinkrow (South African Museum, Cape Town, South Africa) for their kind support concerning specimen examination at the collections. We thank Bruce Patterson for providing information concerning Indian lion specimens kept in the Field Museum, Chicago and for his comments on the manuscript. We also thank an anonymous referee for his/her comments.

\section{References}

Barnett R, Shapiro B, Barnes I, Ho SYW, Burger J, Yamaguchi N, Higham TFG, Wheeler HT, Rosendahl W, Sher AV, Sotnikova M, Kuznetsova T, Baryshnikov GF, Martin LD, Harington CR, Burns JA, Cooper A. 2009. Phylogeography of lions (Panthera leo) reveals three distinct taxa and a late Pleistocene reduction in genetic diversity. Molecular Ecology 18: 1668-1677 
Barnett R, Yamaguchi N, Barnes I, Cooper A. 2006a. The origin, current diversity, and future conservation of the modern lion (Panthera leo). Proceedings of the Royal Society B: Biological Sciences 273: 2119-2125.

Barnett R, Yamaguchi N, Barnes I, Cooper A. 2006b. Lost population and preserving genetic diversity in the lion Panthera leo: implications for its ex situ conservation. Conservation Genetics 7: $507-514$

Barnett R, Yamaguchi N, Shapiro B, Nijman V. 2007. Using ancient DNA techniques to identify the origin of unprovenanced museum specimens, as illustrated by the identification of a $19^{\text {th }}$ century lion from Amsterdam. Contributions to Zoology 76: 87-94.

Barnett R, Yamaguchi N, Shapiro B, Sabin R. 2008. Ancient DNA analysis indicates the first English lions originated from North Africa. Contributions to Zoology 77: 7-16.

Burger J, Rosendahl W, Loreille O, Hemmer H, Eriksson T, Götherström A, Hiller J, Collins MJ, Wess T, Alt KW. 2004. Molecular phylogeny of the extinct cave lion Panthera leo spelaea. Molecular Phylogenetics and Evolution 30: 841-849.

Dharmakumarsinhji KS, Wynter-Blyth MA. 1950. The Gir forest and its lions Part III. Journal of the Bombay Natural History Society 49: 685-694.

Divyabhanusinh C. 2005. The Story of Asia's Lions. Mumbai, Marg Publications.

Driscoll CA, Menotti-Raymond M, Nelson G, Goldstein D, O'Brien SJ. 2002. Genomic microsatellites as evolutionary chronometers: a test in wild cats. Genome Research 12: 414-423.

Fenton LL. 1909. The Kathiawar lion. Journal of the Bombay Natural History Society 19: 4-15.

Joslin P. 1984. The environmental limitations and future of the Asian lion. Journal of the Bombay Natural History Society 81: 648664.

Kinnear NB. 1920. The past and present distribution of the lion in south eastern Asia. Journal of the Bombay Natural History Society 28: 33-39.

Luo SJ, Kim JH, Johnson WE, van der Walt J, Martenson J, Yukhi N, Miquelle DG, Uphyrinka O, Goodrich JM, Quigley HB, Tilson R, Brady G, Martelli P, Subramaniam V, McDougal C, Hean
S, Huang SQ, Pan W, Karanth UK, Sunquist M, Smith JL, O'Brien SJ. 2004. Phylogeography and genetic ancestry of tigers (Panthera tigris). PLoS Biology 2: 2275-2293.

Nowell K, Jackson P. 1996. Wild Cats. Status Survey and Conservation Action Plan. Gland: IUCN.

O’Brien SJ, Joslin P, Smith III GL, Wolfe R, Schaffer N, Heath E, Ott-Joslin J, Rawal PP, Bhattacharjee KK, Martenson JS. 1987. Evidence for African origins of founders of the Asian Lion Species Survival Plan. Zoo Biology 6: 99-116.

O'Regan HJ, Turner A, Sabin RC. 2005. Medieval big cat remains from the Royal Menagerie at the Tower of London. International Journal of Osteoarchaeology 15: 1-10

Pocock RI. 1930. The lions of Asia. Journal of the Bombay Natural History Society 34: 638-665.

Rashid MA, Reuben D. 1992. The Asian Lion. Baroda: Vishal Offset.

Singh HS. 2007. The Gir Lion. Ahmedabad: Pugmark Qmulus.

Smee, W. 1835. Some account of the maneless lions of Guzerat. Transactions of the Zoological Society of London 1: 165-174.

Srivastav A, Srivastav S. 1997. Asian Lion: on the Brink. Dehradun: Bishen Singh Mahendra Pal Singh.

Talbot LM. 1960. Asian lion: Indian lion Panthera leo persica Meyer. Oryx 5: 216-239.

Todd NB. 1965. Metrical and non-metrical variation in the skulls of Gir lions. Journal of the Bombay Natural History Society 62: 507-520.

Wynter-Blyth MA, Dharmakumarsinhji KS. 1950. The Gir forest and its lions Part II. Journal of the Bombay Natural History Society 49: 456-470.

Yamaguchi N, Cooper A, Werdelin L, Macdonald DW. 2004. Evolution of the mane and group-living in the lion (Panthera leo): a review. Journal of Zoology London 263: 329-342.

Received: 18 February 2009

Accepted: 7 July 2009

Published online: 17 September 2009

Editor: V. Nijman 


\section{Appendix 1}

List of examined lion and tiger specimens that have divided infraorbital foramina, extinct North African Barbary lion specimens, and Lidian lion specimens. Specimens are kept in Natural History Museum, London, UK (London), National Museums Scotland, Edinburgh, UK (Edinburgh), Natural History Museum, University of Oxford, Oxford, UK (Oxford), Royal College of Surgeons, London, UK (RCS), National Museum of Natural History, Paris, France (Paris), Zoological Museum, Strasbourg, France (Strasbourg), Zoological Museum, University of Amsterdam, Amsterdam, The Netherlands (Amsterdam), National
Museum of Natural History, Leiden, The Netherlands (Leiden), Swedish Museum of Natural History, Stockholm, Sweden (Stockholm), and Museum of Natural History, Berlin, Germany (Berlin), Senckenberg Research Institute and Natural History Museum, Frankfurt am Main, Germany (Frankfurt), American Museum of Natural History, New York, USA (New York), Field Museum, Chicago, USA (Chicago), and Bombay Natural History Society, Mumbai, India (Mumbai). The position, either left (L) or right (R), of trifuricated (3), bifurcated (2), or undivided normal (1) foramen is also indicated.

\begin{tabular}{|c|c|c|c|}
\hline Museum (ID) & Life stage/Sex & $\mathrm{L} / \mathrm{R}$ & Origin \\
\hline \multicolumn{4}{|c|}{ Lion (originated from outside India) } \\
\hline Paris (1962.2847) & adult/female & $2 / 1$ & Iran \\
\hline Paris (1962.2854) & adult $/$ male & $1 / 2$ & Iran \\
\hline Leiden $(1751)$ & adult/female & $1 / 2$ & Zimbabwe (Rotterdam Zoo, 1929) \\
\hline Stockholm (A59: 5066) & adult/female & $2 / 1$ & south of Lake Edward, east Democratic Republic of Congo (1921) \\
\hline Berlin (55299) & subadult/female & $2 / 1$ & Albert-Edward Lakes, southwest Uganda/Rwanda \\
\hline Berlin (55317) & adult/male & $2 / 1$ & northwest Uhehe, central Tanzania \\
\hline Berlin (55327) & adult/female & $1 / 2$ & Rwanda (1907) \\
\hline \multicolumn{4}{|l|}{ Tiger } \\
\hline Leiden (23085) & adult/male & $2 / 1$ & Sumatra (Rotterdam Zoo, 1957) \\
\hline \multicolumn{4}{|c|}{ Pleistocene European cave lion (fragmented upper right jaw) } \\
\hline Berlin (MBMa14297a) & & $2 / ?$ & Hermannshöhle, Rübeland, Harz, central Germany (Late Pleistocene) \\
\hline \multicolumn{4}{|l|}{ North African Barbary lion } \\
\hline London (1952.10.20.15) & adult/male & $1 / 1$ & $\begin{array}{l}\text { North Africa (assigned based on mitochondrial DNA by Barnett et al. 2008) } \\
(1280-1385)^{\mathrm{f}}\end{array}$ \\
\hline London (1952.10.20.16) & subadult/male & $1 / 1$ & $\begin{array}{l}\text { North Africa (assigned based on mitochondrial DNA by Barnett } \text { et al. 2008) } \\
(1420-1480)^{\mathrm{f}}\end{array}$ \\
\hline Paris (A1873) & adult/female & $1 / 1$ & Algeria $(z o o, 1833)$ \\
\hline Paris (A7912) & adult/male & $1 / 1$ & North Africa $(z o o, 1839)$ \\
\hline Paris (1862.54) & adult/female & $1 / 1$ & Algeria \\
\hline Paris (1882.502) & adult/male & $1 / 1$ & $\begin{array}{l}\text { North Africa (assigned based on mitochondrial DNA by Barnett et al. 2006b) (c. } \\
1830 \text { ) }\end{array}$ \\
\hline Paris (1897.286) & adult/male & $1 / 1$ & North Africa \\
\hline Paris (1196367) & adult/female & $1 / 1$ & Algeria \\
\hline Strasbourg $(939 \mathrm{~h})$ & adult/female & $1 / 1$ & North Africa (before 1890) \\
\hline Stockholm (A58.5287) & adult/female & $1 / 1$ & North Africa (King of Sweden, 1831) \\
\hline Berlin $(15960)$ & adult/female & $1 / 1$ & North Africa \\
\hline Frankfurt (15766) & adult/female & $1 / 1$ & North Africa (Frankfurt Zoo, 1899) \\
\hline \multicolumn{4}{|l|}{ Indian lion } \\
\hline London (1857.2.24.1) & adult/female & $1 / 1$ & Gujarat, northwest India (presented to London Zoo in 1854) \\
\hline London (1919.7.15.18) & adult/female & $2 / 2$ & "India" by Pocock (extracted from one of the Selous' lion skins) ${ }^{g}$ \\
\hline London (1930.6.6.1) & adult/male & $1 / 1$ & Amreli, Kathiawar, Gujarat, northwest India (c. 1910) \\
\hline London (1930.6.6.2) & juvenile/male & $1 / 2$ & Amreli, Kathiawar, Gujarat, northwest India (c. 1910) \\
\hline London (1930.6.6.3) & juvenile/female & $2 / 1$ & Amreli, Kathiawar, Gujarat, northwest India (c. 1910) \\
\hline London (1931.1.5.1) & adult $/$ male & $1 / 2$ & Kathiawar, Gujarat, northwest India (c. 1930 by Maharajah of Nawanagar?) ${ }^{\mathrm{h}}$ \\
\hline London (1931.1.5.2) & adult $/$ male & $1 / 2$ & Gir, Gujarat, northwest India (c. 1930 by Maharajah of Nawanagar?) ${ }^{\mathrm{h}}$ \\
\hline London (1931.4.13.1) & adult/male & $1 / 2$ & Gir, Gujarat, northwest India (before 1931) \\
\hline London (1931.4.13.2) & adult/female & $2 / 2$ & Gir, Gujarat, northwest India (before 1931) \\
\hline London (1943.64) & juvenile/female & $1 / 1$ & Gir, Gujarat, northwest India (1941) \\
\hline London (1945.136) & adult/female & $2 / 1$ & Gujarat, northwest India (London Zoo, 1945) \\
\hline
\end{tabular}




\begin{tabular}{|c|c|c|c|}
\hline${ }^{\mathrm{a}} \mathrm{RCS}(4484)$ & adult/female & $2 / 3$ & north Gujarat, northwest India (1822) (specimen destroyed 1941) \\
\hline${ }^{\mathrm{a}} \mathrm{RCS}(4485)$ & adult/female & $2 / 1$ & northwest India (1830) (specimen destroyed 1941) \\
\hline bSmee-1 & subadult?/male & [2] & Gujarat, northwest India (c. 1830) (specimen lost?) \\
\hline${ }^{\mathrm{b}} \mathrm{Smee}-2$ & & {$[2]$} & Gujarat, northwest India (c. 1830) (specimen lost?) \\
\hline Edinburgh (Z.1995.5) & adult/male & $1 / 1$ & Gir, Gujarat, northwest India (1995) (London Zoo) \\
\hline Edinburgh (Z.2002.185.1) & adult/male & $1 / 2$ & Gir, Gujarat, northwest India (2000) (Zoo de la Boissiere, Nantes) \\
\hline Edinburgh (Z.2001.174.1) & adult/male & $1 / 2$ & Gir-origin, captive-bred (2001) (Ouwehands Dierenpark, Rhenen) \\
\hline Edinburgh (Z.2001.174.2) & adult/female & $2 / 1^{\mathrm{d}}$ & Gir-origin, captive-bred (2001) (Ouwehands Dierenpark, Rhenen) \\
\hline Edinburgh (Z.2009.008) & adult female & $1 / 1$ & Gir-origin, captive-bred (2005) (Chester Zoo) \\
\hline Edinburgh (Z.2009.009) & subadult female & $1 / 2$ & Gir-origin, captive-bred (2005) (Paignton Zoo) \\
\hline Edinburgh (Z.2007.010) & adult male & $1 / 1$ & Gir, Gujarat, northwest India (2006) (Zoo de la Boissiere, Nantes) \\
\hline Edinburgh (Z.2007.093) & adult male & $1 / 2$ & Gir-origin, captive-bred (2006) (Muséum de Besançon, France) \\
\hline Edinburgh (Z.2007.015) & adult/female & $1 / 1$ & Gir-origin, captive-bred (2007) (London Zoo) \\
\hline Edinburgh (Z.2008.004) & adult female & $1 / 2^{\mathrm{e}}$ & Gir-origin, captive-bred (2007) (Twycross Zoo) \\
\hline Edinburgh (Z.2009.024.3) & adult male & $1 / 1$ & Gir-origin, captive-bred (2009) (Dudley Zoo) \\
\hline Edinburgh (Z.1950.101.6) & & $2 / 2$ & India (early $19^{\text {th }}$ century; $\left.<1818 ?\right)$ \\
\hline Oxford (14174) & adult/female & $1 / 1$ & India (1876) \\
\hline Paris (A1884) & adult/female & $1 / 1$ & India (1838) \\
\hline Paris (I-1460) & adult/female & $1 / 1$ & India (1843?) \\
\hline Paris (1873.556) & adult $/$ male & & 1/1 India (1874) \\
\hline Paris (1962.2872) & adult/female & $1 / 1$ & India \\
\hline Amsterdam (710) & adult/male & $1 / 1$ & India (assigned based on mitochondrial DNA by Barnett et al. 2007) (1809) \\
\hline aNew York (54995) & & $1 / 1$ & Gir, Gujarat, northwest India (1929) \\
\hline anew York (54996) & & $2 / 2$ & Gir, Gujarat, northwest India (1929) \\
\hline aChicago (31121) & subadult/male & $2 / 2$ & Gir, Gujarat, northwest India (1929) \\
\hline aMumbai (1254) & & $1 / 2$ & Gir, Gujarat, northwest India (1953-1963) \\
\hline aMumbai (1255) & & $1 / 1$ & Gir, Gujarat, northwest India (1953-1963) \\
\hline aMumbai (1261) & & $1 / ?$ & Gir, Gujarat, northwest India (1953-1963) (right side broken) \\
\hline aMumbai (1267) & & $1 / 1$ & Gir, Gujarat, northwest India (1953-1963) \\
\hline aMumbai (1268) & & $1 / 1$ & Gir, Gujarat, northwest India (1953-1963) \\
\hline aMumbai (1291) & & $1 / 1$ & Gir, Gujarat, northwest India (1953-1963) \\
\hline aMumbai (1292) & & $2 / 1$ & Gir, Gujarat, northwest India (1953-1963) \\
\hline aMumbai (1293) & & $1 / 1$ & Gir, Gujarat, northwest India (1953-1963) \\
\hline aMumbai (1329) & & $1 / 2$ & Gir, Gujarat, northwest India (1953-1963) \\
\hline aMumbai (1353) & & $1 / 1$ & Gir, Gujarat, northwest India (1953-1963) \\
\hline aMumbai (1363) & & $1 / 1$ & Gir, Gujarat, northwest India (1953-1963) \\
\hline aMumbai (1364) & & $1 / 1$ & Gir, Gujarat, northwest India (1953-1963) \\
\hline aMumbai (1389) & & $1 / 1$ & Gir, Gujarat, northwest India (1953-1963) \\
\hline aMumbai (1391) & & $1 / 2$ & Gir, Gujarat, northwest India (1953-1963) \\
\hline aMumbai (1392) & & $1 / 1$ & Gir, Gujarat, northwest India (1953-1963) \\
\hline aMumbai (1393) & & $1 / 1$ & Gir, Gujarat, northwest India (1953-1963) \\
\hline aMumbai (1396) & & $1 / 1$ & Gir, Gujarat, northwest India (1953-1963) \\
\hline aMumbai (5744) & & $1 / 1$ & Gir, Gujarat, northwest India (1931) \\
\hline a'Mumbai (5926) & & $1 / 1$ & Gir, Gujarat, northwest India (c. 1931) \\
\hline aMumbai (no ID-1) & & $2 / 2$ & Gir, Gujarat, northwest India (1953-1963) \\
\hline aMumbai (no ID-2) & & $1 / 1$ & Gir, Gujarat, northwest India (1953-1963) \\
\hline
\end{tabular}




